\title{
Interaksi Beberapa Senyawa Kalkon Berbasis Parasetamol terhadap Protein Enzim yang Berperan dalam Mekanisme Antibakteri
}

\author{
Anasda Amal Fathullah ${ }^{1}$, Wisnu Cahyo Prabowo ${ }^{2}$, Rolan Rusli ${ }^{1,2, *}$ \\ ${ }^{1}$ Laboratorium Penelitian dan Pengembangan Kefarmasian "Farmaka Tropis", \\ Fakultas Farmasi, Universitas Mulawarman, Samarinda, Indonesia \\ ${ }^{2}$ Kelompok Bidang Ilmu Kimia Farmasi, Fakultas Farmasi, Universitas Mulawarman, Samarinda, Indonesia \\ *E-mail: rolan@farmasi.unmul.ac.id
}

\begin{abstract}
Abstrak
Kalkon merupakan metabolit sekunder dari golongan flavonoid yang banyak ditemukan di alam terutama pada tumbuh-tumbuhan. Kalkon memiliki berbagai aktivitas seperti sitotoksik, antivirus, anestesi, antimikroba, antiinflamasi, dan lain sebagainya. Tujuan penelitian ini adalah untuk mengetahui aktivitas antibakteri senyawa turunan kalkon berbasis parasetamol dengan menggunakan metode docking terhadap protein bakteri Escherichia coli dan Bacillus subtilis. Hasil penelitian menunjukkan bahwa senyawa 3-(4-Metoksifenil)-N-(4-Klorofenil) Akrilamida, 3-(4-Hidroksifenil)-N(4-Klorofenil) Akrilamida, dan 3-(4-Hidroksi-3-Metoksifenil)-N-(4-Klorofenil) Akrilamida menunjukkan aktivitas yang baik dengan rata-rata skor rmsd-refine <2. Turunan kalkon tersebut berikatan kompleks dengan asam amino bakteri seperti Ile 173, Asn 267, Lys A449, Thr 265, dan Arg A389.
\end{abstract}

Kata Kunci: Bacillus subtilis, Docking, Escherichia coli, Turunan Kalkon

\begin{abstract}
Kalkon is a secondary metabolite of the flavonoid group that is found in nature, especially in plants. Kalkon has various activities such as cytotoxic, antiviral, anesthetic, antimicrobial, antiinflammatory, and so forth. The aim of this research is to know the antibacterial activity of kacco-based derived paracetamol compound by using docking method against bacterial protein Escherichia coli and Bacillus subtilis. The results showed that the compound 3- (4-Metoxyphenyl) - $\mathrm{N}$ - (4-Chlorophenyl) Acrylamide, 3- (4-Hydroxyphenyl) - N- (4-Chlorophenyl) Acrylamide, and 3- (4-Hydroxy-3-Methoxyphenyl) - $\mathrm{N}$ - (4Chlorophenyl) Acrylamide showed good activity with an average rmsd-refine score $<2$. The kalkon derivative binds complex with amino acid bacteria such as Ile 173, Asn 267, Lys A449, Thr 265, and Arg A389.
\end{abstract}

Keywords: Bacillus subtilis, Calcon derivated, Docking, Escherichia coli

\section{Pendahuluan}

Kalkon merupakan metabolit sekunder dari golongan flavonoid yang banyak ditemukan di alam terutama pada tumbuh-tumbuhan. Kalkon dikenal sebagai perantara sintesis berbagai macam senyawa heterosiklik. Berdasarkan beberapa penelitian yang telah dilakukan, kalkon telah dilaporkan memiliki berbagai macam aktivitas biologis antara lain sebagai antimikroba, antimalaria, antiinflamasi, analgesik, antiplatelet, antivirus, antileismania, antioksidan, penghambatan pelepasan mediator kimia, penghambat leukotrien B4, penghambatan tirosinase, dan penghambatan aktivitas aldose reduktase [1].
Berdasarkan laporan penelitian penyakit yang disebabkan oleh bakteri masih memiliki tingkat prevalensi tinggi bagi sebagian besar masyarakat di Indonesia. Pada kenyataannya obat-obatan antibakteri sekarang banyak yang menimbulkan resistensi pada sebagian orang, sebagian kasus timbul reaksi hipersensitivitas dan efek samping obat lainnya yang tidak diinginkan. Semakin banyak suatu antibiotik digunakan semakin banyak timbul resistensi kuman, dan meningkatnya efek samping yang merugikan [2].

Penelitian inhibisi antibakteri terus meningkat. Salah satunya adalah penelitian tentang turunan kalkon. Gambaran unik pada antibakteri adalah selektivitas dalam penghambatannya baik pada bakteri gram positif maupun gram negatif. Hal ini 
dapat menjadi target rancangan obat rasional dan efektif untuk obat-obatan antibakteri. Saat ini, pendekatan molekul doking telah banyak digunakan dalam rancangan obat modern untuk membantu memahami interaksi obat dengan reseptor. Telah banyak ditunjukkan dalam literatur bahwa teknik komputasi dapat mendukung dan membantu desain turunan senyawa untuk mendapatkan inhibitor yangclebih ampuh melalui mekanisme interaksi obat-reseptor [3].

Molekular docking adalah alat utama dalam biologi molekular struktural dengan bantuan komputer untuk desain suatu obat. Tujuan dari docking protein dan ligan yaitu untuk memprediksi model yang mengikat ligan pada daerah yang dominan yang dikenal dengan protein pada struktur tiga-dimensi. Dalam penelitian ini digunakan docking secara cepat dan fleksibel untuk mempelajari dan memprediksi orientasi dan afinitas ikatan dari turunan kalkon berbasis parasetanol dengan menggunakan $M O E$ Molecular Docking Computing. Penelitian ini dilakukan untuk memahami bentuk-bentuk interaksi dari 3 senyawa turunan kalkon berbasis parasetamol terhadap Bacillus subtilis dan Escherichia coli [3].

\section{Metode Penelitian}

\subsection{Struktur Molekul dan Optimasi}

Optimasi geometri struktur dilakukan dengan program HyperChem 8.0 for Windows Molecular Modeling System. Pembuatan struktur meliputi pembuatan kerangka dasar, dan penambahan atom hidrogen. Optimasi dilakukan dengan menyesuaikan sudut-sudut ikatannya. Struktur dioptimasi dengan metode ab-initio hingga diperoleh struktur stabil. Struktur protein pada Bacillus subtilis (PDB kode 2J9P) dan Escherichia coli (PDB kode 3BEC) diperoleh dari Bank Data Protein.

\subsection{Protein}

Struktur Bacillus subtilis (PDB kode 2J9P) dan Escherichia coli (PDB kode 3BEC) kompleks yang beresolusi-tinggi (2,50 Ao). Simulasi ikatan dilakukan dengan substrat peptidoglycan mimetic peptide tanpa molekul air untuk menjelaskan peran hambatan terhadap bakteri.

\subsection{Validasi Metode Docking}

Program MOE Molecular Docking Computing divalidasi untuk mendapatkan metode yang reliable. Struktur protein didapatkan dari Protein Data Bank (situs www.rcsb.org/pdb/). Analisa data perbandingan scoring dinyatakan dengan RMSD (Rate Mean Square Deviation). Metode docking dikatakan baik jika nilai RMSD-nya lebih kecil sama dengan dua $(\leq 2)$. Jika nilai RMSD yang diperoleh lebih besar dari $2(>2)$, metode yang digunakan tidak reliabel.

\section{Hasil dan Pembahasan}

Perancangan struktur senyawa kalkon berbasis parasetamol dilakukan dengan menggunakan program hyperchem $8.0^{\circledR}$. Struktur dibuat dan dioptimasi, optimasi struktur yang digunakan menggunakan metode ab-initio. Metode ini digunakan karena memiliki tingkat ke akuratan yang lebih tinggi dibandingkan dengan metode lainnya. Metode ab-initio bergantung dari kemampuan komputer yang digunakan, karena metode ini menggunakan waktu yang cukup lama untuk melakukan optimasi struktur, media simpan dan memori komputer. Setelah memilih metode yang digunakan pemilihan basis juga merupakan bagian yang penting dari keberhasilan doking. Setelah basis sudah diset proses optimasi akan berlangsung. Lamanya waktu optimasi tergantung dari struktur yang dirancang. Struktur senyawa hasil optimasi dapat dilihat pada Gambar 1.

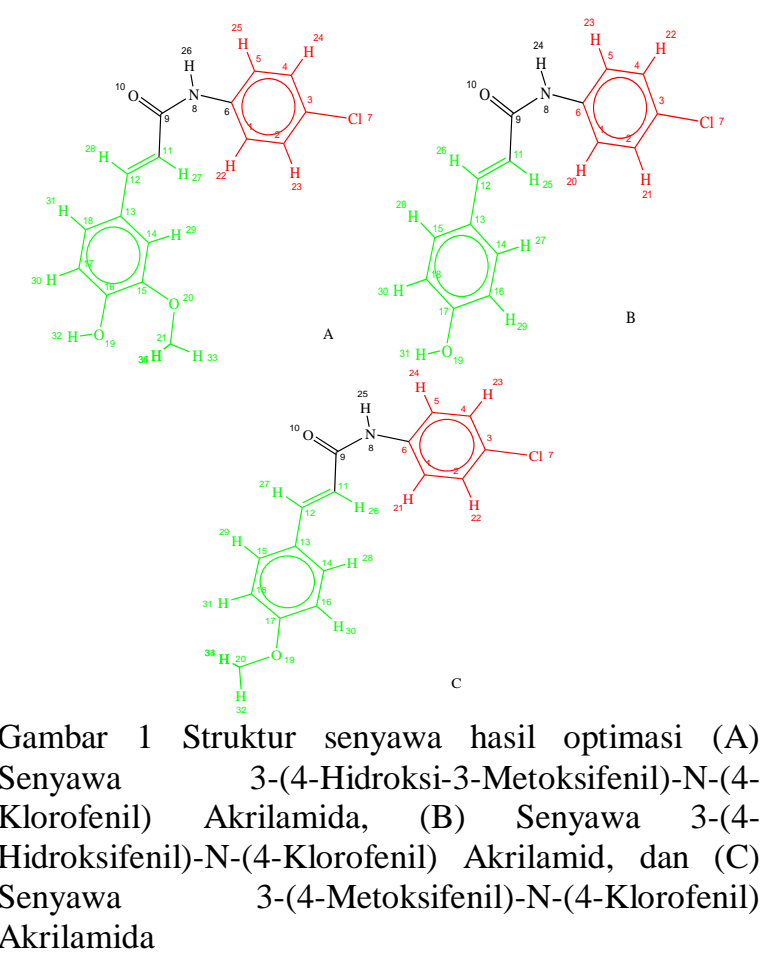


Hasil optimasi struktur menunjukkan nilai panjang ikatan, nilai sudut ikatan dan nilai sudut dihendral senyawa turunan kalkon berbasis parasetamol. Sudut ikatan adalah sudut yang dibentuk antara sepasang atom yang terikat dengan satu atom lain. Panjang ikatan yaitu jarak antara dua buah inti atom yang saling terikat. Sudut dihedral yaitu sudut antara suatu atom dengan bidang yang dibentuk oleh tiga atom lain. Berdasarkan hasil optimasi struktur senyawa 1 yang memiliki nilai ikatan $\mathrm{C}_{1}-\mathrm{C}_{18}$ memiliki nilai persen kedekatan dengan teori sebesar 97,7-120,2 $\%$, untuk nilai sudut ikatan $\mathrm{C}-\mathrm{C}-\mathrm{C}$ memiliki nilai sebesar 98,2-105,5\% dan nilai sudut dihedral sebesar 99,9-100\%. Pada senyawa 2 memiliki nilai ikatan $\mathrm{C}_{1}-\mathrm{C}_{18}$ memiliki nilai persen kedekatan dengan teori sebesar 97,6-112,8\%, untuk nilai sudut ikatan C-C-C memiliki nilai sebesar 98,2-120,2\% dan nilai sudut dihedral sebesar 99,9-100\%. Pada senyawa 3 memiliki ikatan $\mathrm{C}_{1}-\mathrm{C}_{18}$ memiliki nilai persen kedekatan dengan teori sebesar 97,6-112,9\%, untuk nilai sudut ikatan C-C-C memiliki nilai sebesar 98,1$105,6 \%$ dan nilai sudut dihedral sebesar 99,9$100 \%$ [4].

Tabel 1. Parameter doking ligan sisi aktif bakteri Bacillus subtilis

\begin{tabular}{ccc}
\hline Senyawa & $\mathrm{S}(\mathrm{kcal} / \mathrm{mol})$ & Rmsd_refine \\
\hline 1 & $-11,1036$ & 0,9333 \\
2 & $-10,0520$ & 0,7816 \\
3 & $-7,9017$ & 1,2612 \\
\hline
\end{tabular}

Tabel 2. Interaksi ligan (obat) dan reseptor Bacillus subtilis

\begin{tabular}{ccccc}
\hline Senyawa & Lys & Arg & Ser & Thr \\
& 449 & 389 & 399 & 294 \\
\hline 1 & - & - & - & - \\
2 & - & + & - & - \\
3 & + & - & - & - \\
\hline
\end{tabular}

Keterangan : $\quad(+)=$ Terjadi interaksi

$(-)=$ Tidak ada interaksi

Berdasarkan Tabel 1 menunjukkan bahwa senyawa turunan kalkon berbasis parasetamol yang tersubstitusi $\mathrm{OH}$, dan $\mathrm{OCH}_{3}$ memiliki aktivitas yang cukup baik terhadap bakteri Bacillus subtilis. Nilai rmsd_refine merupakan nilai acuan senyawa uji dengan senyawa pembanding. Senyawa pembanding yang dimaksud adalah senyawa yang sudah ada di dalam protein dari bakteri tersebut dan senyawa pembanding tersebut adalah penisilin. Sedangkan nilai $\mathrm{S}$ merupakan energi bebas ikatan protein.
Berdasarkan hasil doking parameter ligan sisi aktif bakteri bacillus subtilis diperoleh nilai rmsd_refine senyawa rata-rata kurang dari $2(<2)$. Senyawa uji dengan tersubstitusi kloro memiliki nilai yang paling dekat dengan senyawa acuan yaitu $0,7399 \mathrm{kcal} / \mathrm{mol}$ dan memiliki nilai energi bebas ikatan protein sebesar -7.9909. Nilai negatif yang didapatkan dari energi ikatan bebas protein adalah menunjukan bahwa reaksi yang terjadi secara spontan, jika hasil yang didapatkan bernilai positif maka reaksi tidak spontan atau tidak dapat terjadi. Berdasarkan penelitian yang dilakukan oleh Susmi [5] nilai Root Mean Square Deviation (RMSD) yang umunya digunakan sebagai nilai standar penambatan molekul adalah sebesar $<2$. Semakin mendekati nol maka nilai kedekatan senyawa uji semakin dekat dengan pembanding. Pada bakteri bacillus subtilis senyawa kalkon berinteraksi dengan protein Arg 389 dan Lys 411 (Tabel 2).

Pada interaksi senyawa uji dengan protein enzim Arg 389 terjadi interaksi arene-cation yang melibatkan cincin aromatik pada senyawa uji. Interaksi lainnya yang terjadi adalah interaksi sidechain acceptors antara senyawa turunan kalkon yang tersubstitusi gugus hidroksi $(\mathrm{OH})$ dengan Protein enzim Lys 411. Fungsi arginin dan lysin pada bakteri adalah memfasilitasi produksi enzim, hormon dan antibodi. Lisin juga membantu dalam sintesis kolagen dan jaringan ikat. Peptidoglikan merupakan komponen utama dinding sel bakteri yang bersifat kaku dan bertanggungjawab untuk menjaga integritas sel serta menentukan bentuknya. Pembentukan struktur pepidoglikan dibantu oleh enzim transpeptidase yang berfungsi untuk menyambung antara satu unit peptidoglikan dengan yang lainnya. Apabila arginin dan lisin dihambat maka produksi enzim transpeptidase akan terhambat sehingga struktur peptidoglikan tidak dapat dibentuk hal ini menyebabkan dinding sel bakteri menjadi tidak kokoh dan apabila sel bakteri tumbuh dengan dinding sel yang kurang sempurna maka bertambahnya plasma atau air yang terserap dengan jalan osmosis akan menyebabkan dinding sel bakteri menjadi lisis. Pada senyawa turunan kalkon cincin aromatis bersifat aktif sehingga turunan kalkon dapat mengikat ke sisi aktif bakteri bacillus subtillis, hal ini sesuai dengan interaksi yang ada pada senyawa turunan kalkon berbasis parasetamol yang menggunakan cincin aromatis untuk berinteraksi. Menurut Harjono [6] semakin besar energi ikatan bebas protein yang ditunjukkan dengan nilai (S) berarti ikatan tersebut semakin stabil. Semakin stabil ikatan 
antara ligan dengan reseptor maka dapat diprediksikan bahwa aktivitasnya juga semakin besar.

Tabel 3. Parameter doking ligan sisi aktif bakteri Escherichia coli

\begin{tabular}{ccc}
\hline Senyawa & $\mathrm{S}(\mathrm{kcal} / \mathrm{mol})$ & Rmsd_refine \\
\hline 1 & $-8,7600$ & 0,9060 \\
2 & $-5,9769$ & 1,0820 \\
3 & $-9,1756$ & 0,7861 \\
\hline
\end{tabular}

Tabel 4. Interaksi ligan (obat) dan reseptor Escherichia coli

\begin{tabular}{ccccc}
\hline Senyawa & Thr & Tyr & Asn & Arg \\
& 265 & 297 & 267 & 174 \\
\hline 1 & - & - & - & - \\
2 & + & - & - & - \\
3 & - & - & - & - \\
\hline Keterangan : & \multicolumn{2}{l}{ (+) Terjadi interaksi } & \\
& $(-)=$ Tidak ada interaksi &
\end{tabular}

Hasil parameter doking senyawa turunan kalkon berbasis parasetamol terhadap bakteri escherichia coli juga menggunakan protokol yang sama dengan bacillus subtilis. Berdasarkan tabel 3 nilai skroring kedekatan senyawa uji dengan senyawa acuan yang ada pada protein bakteri memiliki nilai rata-rata kurang dari $2 \quad(<2)$. Senyawa uji yang tersubstitusi metoksi memiliki nilai yang paling dekat dengan senyawa acuan yang ada pada protein bakteri yaitu 0,7861 . Senyawa acuan yang ada pada bakteri Escherichia adalah Cepalosphorin.

Golongan gram negatif memiliki lapisan peptidoglikan yang tipis $(5-10 \mathrm{~nm})$ dengan komposisi utama lipoprotein dan lipopolisakarida. Membran luarnya merupakan struktur bilayer.

Pada bakteri escherichia coli terjadi interaksi antara senyawa turunan kalkon berbasis parasetamol terhadap protein enzim $\mathrm{Thr} 265$ (Tabel 4). Interaksi yang terjadi adalah interaksi backbond acceptor yang melibatkan atom hidrogen yang ada pada gugus Hidroksi berinteraksi dengan protein enzim Treonin. Fungsi asam amino treonin adalah meningkatkan sistem kekebalan dan membantu dalam produksi antibodi. Apabila treonin dihambat maka akan menyebabkan ketahanan dari bakteri mudah ditembus dan menyebabkan terganggunya sintesis peptidoglikan lapisan dinding sel bakteri, sehingga bakteri akan musnah. Pengujian secara in-vitro terhadap senyawa turunan kalkon hasil yang didapatkan baik pada bakteri escherichia coli dan bacillus subtilis lebih kecil dibandingkan dengan kloramfenikol dan didapatkan bahwa senyawa turunan kalkon berinteraksi dengan protein Lys 411, Thr 412 dan Ser 52 [7].

\section{Kesimpulan}

Berdasarkan data hasil parameter doking sisi aktif ligan bakteri escherichia coli dan bacillus subtilis, menunjukkan BAHWA senyawa kalkon berbasis parasetamol memiliki aktivitas yang baik terhadap bakteri Escherichia coli dan Bacillus subtilis dengan nilai kedekatan terhadap senyawa acuan $<2$ dan berinteraksi dengan protein enzim Lys 411, Thr 265 dan Arg 389.

\section{Daftar Pustaka}

[1] Prasad, Y. R., Rao, A. L., Rambabu, R., 2008. Synthesis and Antimicrobial Activity of Some Chalcone Derivatives. E-Journal of Chemistry. 5 (3): 461-466.

[2] Hart, T \& Shears, P. Atlas Berwarna Mikrobiologi Kedokteran. Jakarta: Penerbit Hipokrates, 1996: 71-226

[3] Wattimena, J. R., Sugiarso, N. C., Widianto, M. B., Sukandar, E. Y., Soemardji, A. A., dan Setiadi, A. R. Farmakodinamik dan Terapi Antibiotik. Yogyakarta: Gadjah Mada University Press, 1991: 3-50

[4] Mc Murry, J., 2016. Organic Chemistry, Ninth Edition. Cengage Learning. Boston. USA.

[5] Susmi, dkk, 2017. Studi Docking Molekular Senyawa Asam Sinamat dan Derivatnya Sebagai Inhibitor Protein 1J4X Pada Sel Kanker Serviks. Jurnal Kimia Mulawarman. Vol 14(12)

[6] Harjono, S., 2013. Quantitative StructureCytotoxic Activity Relationship 1(Benzoyloxy)urea and Its Derivates. Current Drug Discovery Technology. Vol.13(2): 101108

[7] Rosita, Ayik. 2012. Molekular Docking dengan Metode Molegro Vitual Docker Turunan Kalkon Antimikroba. Jurnal Unej. Vol 9 (1): 39-47 